\title{
Do direct-access and indirect-access adaptation projects differ in their focus on local communities? A systematic analysis of 63 Adaptation Fund projects
}

\author{
Ornsaran Pomme Manuamorn ${ }^{1,2}$ (D) Robbert Biesbroek $^{1}$ (D) \\ Received: 31 July 2019 / Accepted: 22 October 2020 / Published online: 26 November 2020 \\ (C) The Author(s) 2020
}

\begin{abstract}
Recent literature suggests that direct national access to multilateral climate funds could promote climate change adaptation investment that focuses more on the needs of vulnerable local communities when compared to indirect access through multilateral agencies. However, there has been no systematic comparative assessment of the level of community focus of direct-access and indirect-access projects. The lack of a standardized methodology to assess the level of community-focused adaptation has also constrained such comparison. To address this gap, this paper proposes a new framework to assess the level of community focus in adaptation projects, using a combination of financial, participatory, devolutionary, and design for policy adoption and replicability criteria. Using the Adaptation Fund (AF) as a case study, we apply the framework to systematically assess 63 projects approved by the Fund as of May 2017, comprising 22 direct-access and 41 indirect-access projects. We find that directaccess projects are more community-focused than indirect-access projects because they exhibit higher community-oriented financial, participatory, and devolutionary characteristics. We find no difference between the direct-access and indirect-access projects with regard to how they are designed to promote policy adoption and replicability of AF project-financed adaptation actions through policy and geographical mainstreaming. Our findings contribute to an improved understanding of the pattern of adaptation investment that takes place in developing countries with the support of international adaptation finance under both access modalities. The proposed assessment framework could also inform the development of a standardized methodology to track the delivery of international adaptation finance to the community level.
\end{abstract}

Keywords Climate change adaptation $\cdot$ Climate finance $\cdot$ Participation $\cdot$ Devolution $\cdot$ Community $\cdot$ Adaptation Fund

\section{Introduction}

The Adaptation Fund (AF) is recognized for pioneering the direct access modality, which allows national institutions in

Communicated by Chandni Singh

Supplementary Information The online version contains supplementary material available at https://doi.org/10.1007/s10113-02001716-4.

Ornsaran Pomme Manuamorn o.manuamorn@student.maastrichtuniversity.nl

1 Public Administration and Policy Group, Wageningen University \& Research, Wageningen, The Netherlands

2 Maastricht Graduate School of Governance (MGSoG), UNU MERIT, Maastricht University, Boschstraat 24, 6211

AX Maastricht, The Netherlands developing countries to access international adaptation finance directly without using international intermediaries such as multilateral development banks (Adaptation Fund 2012; Schäfer et al. 2014). Direct access is not new to development finance but is innovative for international adaptation finance (Brown et al. 2010). The AF was the first multilateral climate fund to pioneer direct access on a regular basis, along with providing indirect access through international intermediaries. The AF's introduction of direct access reflects an international political economy in which developing countries increasingly demand a more country-led operating instrument of global climate finance (Harmeling and Kaloga 2011; Horstmann 2011).

Access modality refers to "the institutional architecture through which funding decisions are made and finance flows (Bird 2014, p.6)". As such, it constitutes a key governance context shaping the fund-recipient relationships and the characteristics of adaptation projects being financed. Under the 
indirect-access modality, developing countries access AF funding through international organizations accredited as multilateral implementing entities (MIEs) or regional implementing entities (RIEs). MIEs and RIEs identify, develop, implement, and monitor projects for developing countries in collaboration with executing entities (EEs), which could be national, subnational, or local organizations and are accountable for the overall fund use on behalf of the recipient countries (AFB 2008). Under the direct-access modality, all of these functions of MIEs or RIEs are performed by national institutions accredited as national implementing entities (NIEs). According to the AF operational guideline (AFB 2008), NIEs, MIEs, and RIEs all have the same roles and responsibilities with regard to designing, implementing, and monitoring AF projects. But while the roles and responsibilities of these implementing entities are the same on paper, in practice the direct-access modality is structurally more decentralized to the national level. At the same time, the knowledge, capacity, and incentives of national and international organizations vary, and these differences could carry implications for how adaptation interventions are designed and implemented.

Direct access generates a strong interest from the international climate community but the current discourse on the advantages and challenges of the modality is shaped by divergent views. Some donors perceive direct assess as potentially accelerating climate finance delivery but not as a default option due to concerns about transparency, accountability, and risk management at the recipient-country level (Bird et al. 2011). Developing countries and civil society, on the other hand, praise the modality for being country-driven and argue that it should be a key design principle of future global climate financing mechanisms (IIED 2014; UNFCCC 2010). The latter position has gained some momentum with the adoption of direct access by the Green Climate Fund (GCF) (GCF 2015). However, indirect access had been the norm in international adaptation finance and remains the most dominant access modality today (Duus-Otterström 2016).

Much of the current literature on direct access discusses its key features and the implications on the recipient country-fund relationships (Bird 2014; Brown et al. 2010; Druce et al. 2013; Harmeling and Kaloga 2010). Some scholars examine supportive and opposing arguments for the modality (Craeynest et al. 2010; Duus-Otterström 2016). Recent studies began to assess the operationalization experience of the modality (Druce et al. 2013; Masullo et al. 2015; Schäfer et al. 2014; UNDP 2012), focusing on lessons learned from accredited national institutions and making recommendations to improve the $\mathrm{AF}$ accreditation procedures to accelerate direct access. Given the interest in direct access as a novel mechanism to channel international adaptation finance to developing countries when compared to indirect access, it is surprising that little attention has been given to comparing the projects funded by the two modalities in practice, even though it has been since 2010 that they are operating in parallel.

This paper compares direct-access and indirect-access $\mathrm{AF}$ projects on their adaptation investment at the community level. The analysis that follows is guided by the following empirical research question: are direct-access and indirect-access adaptation projects equally communityfocused? Three reasons provide the rationale for this comparison. First, the AF has been recognized for its success in reaching the most climate-vulnerable populations including local communities and marginalized groups (Fenton et al. 2014). But while the direct-access modality has been credited as a key factor for such success (Fenton et al. 2014), there has been no research which compares the level of community focus of direct-access and indirect-access projects within the AF portfolio. Second, while the AF's mandate prioritizes most vulnerable local communities, the $\mathrm{AF}$ does not have a dedicated community-financing window like other funds, for example, the community-based adaptation (CBA) pilot program of the Global Environment Facility Small Grant programs (Huq and Faulkner 2013). We could therefore expect to see the different degrees of emphasis on community-based approaches in AF projects as a result of context-specific negotiation among stakeholders. Third, the focus of the research design on just the $\mathrm{AF}$ automatically controls for a set of AF-specific factors that would likely have biased a comparison of direct-access and indirect-access projects from different climate funds. However, since there is currently no standard methodology to systematically report and track community-level adaptation financing (Fenton et al. 2014), a new framework needs to be developed for the proposed project comparison.

The purpose of this paper is therefore threefold. First, it develops a new framework to assess the level of community focus in adaptation projects. Second, it tests the framework by assessing the level of community focus in AF projects. Third, it compares if direct-access and indirect-access projects differ in terms of the level of community focus. Answering this third question is highly relevant to the study of international adaptation finance. Given that the $\mathrm{AF}$ is seen as a potential model for other multilateral climate funds (Horstmann 2011), findings from this assessment could inform the operations of those funds, particularly the GCF which has adopted the directaccess modality, accredited 14 NIEs and 6 RIEs of the AF as its own implementing entities, and is financing the upscaling of AF projects in various countries. We argue that a meaningful systematic comparison of direct-access and indirect-access projects was only recently enabled by the AF's approval of more direct-access projects since 2013, thus adding more comparison cases from the direct-access side. While recent papers performed qualitative analysis of AF projects (Persson and Remling 2014; Remling and Persson 2015), to the best of our knowledge, this is the first paper that 
systematically compares the two modalities on the design characteristics of adaptation projects.

The paper is organized as follows. "Conceptual framework" proposes a conceptual framework to assess the level of community focus in adaptation projects. "Data and methods" describes the paper's methodology and data analysis. "Results" presents results from the systematic analysis of 63 AF projects. "Discussions" discusses the findings. "Conclusion" provides a conclusion.

\section{Conceptual framework}

There is currently no established framework and methodology to assess climate finance for community-focused adaptation. Based on a search of the recent climate finance tracking literature, we identify two seminal papers by Fenton et al. (2015) and Soanes et al. (2017) that seek to develop such a framework and identify its key components. The three key components similarly identified by both papers are: (1) a definition of who are community-level beneficiaries of adaptation finance; (2) a quantitative tracking of each project's financial investment in activities that generate direct adaptation benefits for these beneficiaries; and (3) an assessment of the qualitative characteristics of the project processes and activities that reflect key design principles of locally driven adaptation at the community level. In this study, we use these three components as a starting point to further elaborate our framework to assess the level of community focus in adaptation projects. The following section discusses the definition of community-level beneficiaries ("Community-level beneficiaries of international adaptation finance"), which forms the basis for our design of quantitative tracking ("Financial investment at the community level") and qualitative assessment ("Qualitative characteristics of locally driven adaptation at the community level") of communityfocused adaptation in this paper.

\section{Community-level beneficiaries of international adaptation finance}

We further consult the CBA literature to understand who can be defined as community-level beneficiaries of international adaptation finance and use such definition to guide the coding of AF project documents (see "Operational indicators for assessment"). Drawing on the CBA literature, we define beneficiaries of international adaptation finance at the community level to comprise groups of households, villages, communes, neighborhoods, and settlements in climate-vulnerable locations (Ayers and Forsyth 2009; Reid et al. 2010). Populations living in these settings are often conceptualized as place-based local communities such as rural communities, farming communities, coastal communities, etc. They are recognized as being internally diverse and do not always have stable populations and boundaries (Buggy and McNamara 2016; Kirkby et al. 2017), but at the same time share common characteristics, beliefs, and/or actions that shape their collective exposure to climate change (Agrawal 2008), as well as the ability to adapt to it (Dodman and Mitlin 2013). Community actors, such as individual community members, smallholder producer groups, women groups, community leaders and community-based organizations (CBOs), etc., can be distinguished from other local but more upwardly located actors such as cities, municipalities, and districts. Internationally funded adaptation projects that support bottom-up approaches usually target these community actors as project beneficiaries in practice (Adaptation Fund 2013, 2014; GCF 2018; Huq and Faulkner 2013). Apart from promoting technical adaptation measures that build on local knowledge and practices, project activities usually incorporate on-site capacity building for these community actors.

It should be noted that the use of the above definition of community-level beneficiaries does not presuppose the notions of harmony and equality that ignore the power politics and structural inequities between community sub-groups (McDonnell 2019; Titz et al. 2018). It is well recognized that bottom-up approaches such as CBA face a difficulty in defining a real-life community and its members, that community power relations are unequal, and that the notion of community can be used to morally justify external interventions as people-centered, while the benefits are in fact captured by local elites (Buggy and McNamara 2016; Kepe 1999; McDonnell 2019; Schipper et al. 2014). The purpose of defining community-level beneficiaries in this study is primarily to understand who are targeted for AF community-level interventions in order to initially compare the design of direct-access and indirect-access projects, without precluding future studies that will assess them with more critical perspectives.

\section{Financial investment at the community level}

Quantifying the amount of adaptation finance designated for local actions is fundamental to tracking adaptation finance at the local level (Fenton et al. 2015; Soanes et al. 2017). Building on Fenton et al. (2015) and Soanes et al. (2017), we therefore track the amount of project funding within each AF project that flows to community-level activities, which are defined as AF project activities that generate direct benefits for community-level beneficiaries as discussed in "Communitylevel beneficiaries of international adaptation finance." Examples are the introduction of climate-resilient agricultural technologies to farming communities, the construction of new village water harvesting infrastructure, capacity building for villagers and CBOs for community-based resource management, etc. (see Supplementary material 3). Excluded from 
community-level investment are AF project activities that build infrastructure above the community scale, conduct technical analyses, improve capacity of government institutions, and/or strengthen overall policy and regulatory frameworks.

\section{Qualitative characteristics of locally driven adaptation at the community level}

Drawing from the literature on CBA and participatory development, we propose to assess each AF project for three qualitative characteristics that reflect the key design principles of community-focused adaptation: (1) the level of community participation during project design and implementation; (2) the level of devolution of decision-making power to community-level actors; and (3) the design for policy adoption and replicability of community adaptation activities.

\section{Community participation}

Here, we refer to participation as public participation in the context of climate change adaptation, which Few et al. (2007) describe as "securing the active involvement of a broad range of stakeholders in decision-making and action for anticipatory adaptation through processes coordinated by governments and other agencies (p. 47)." Public participation is often used interchangeably with stakeholder participation since the focus is on engaging those with stakes in the decision-making rather than a general public (Reed 2008). The participatory development movement calls for bottom-up involvement of beneficiaries as informed participants in the design and management of development projects that affect them (Chambers 1983, 1994; Mansuri and Rao 2003; United Nations 2008). Cleaver (1999) summarizes the two strands of arguments for participatory development; the first are efficiency arguments which espouse participation as means to achieve better project outcomes. Here, participation is seen as a pragmatic way to identify development priorities by asking the beneficiaries themselves, resulting in a project which is more relevant, targeted, and accepted. The second are empowerment arguments which see participation as a desirable end. Here participation is considered a transformational process that builds capacities of the individuals to improve their lives and affect positive social change (Cleaver 1999). In practice, the two strands are often used jointly in justifying participatory development projects.

Literature on public participation in environmental decision making provides various typologies of stakeholder participation (Reed 2008). Building on Pretty et al. (1995) and Conde et al. (2005), Carter et al. (2007) present a typology of participation in decision-making on climate change adaptation, which can be simplified into three ladders: (1) selfmobilization is the most active form of public participation that takes place when local stakeholders initiate and control the project and solicit external assistance; (2) partnership is the second most active form of participation, which represents when local stakeholders act as equal partners to the project proponent and contribute own resources, ideas, and leadership to the consultative process; and (3) consultation is considered the most basic form of public participation, which takes place when local stakeholders collaborate in a process driven by a third party, are dependent on external resources, and their inputs are used to tailor the pre-identified project design and ensure relevant results.

Community-focused adaptation requires active participation of community stakeholders in project design and implementation (Dodman and Mitlin 2013; Forsyth 2013; Lasage et al. 2015; Sherman and Ford 2014). During the project design phase, participatory consultation approaches could help ensure that the proposed externally financed interventions address the most relevant local adaptation needs and that the selection of project beneficiaries is inclusive (Kirkby et al. 2015; Reed 2008; van Aalst et al. 2008). Continued community participation in project implementation is also important for ensuring project effectiveness, transparency, and accountability. Stakeholder participation is particularly central to community-focused adaptation initiatives that adopt the CBA approach. CBA generates adaptation strategies through participatory processes involving both local stakeholders and external experts, with an objective to synthesize scientific knowledge from external experts with local knowledge and customs to identify locally appropriate adaptation options (Ayers and Forsyth 2009; Piccolella 2013; Reid et al. 2010). These processes draw heavily on participatory approaches and methods developed in the fields of disaster risk reduction, community development and farmer-led participatory research (Reid et al. 2010). However, scholars caution that participation processes are not devoid of norms, expectations, framings, and ideologies (Lebel et al. 2018; Sprain 2017), and if implemented uncritically, could be captured by elites, exacerbate hierarchies, and exclusions, and result in undemocratic outcomes (Sprain 2017).

\section{Devolved decision-making}

The terms "devolution" and "decentralization" are often used interchangeably in discussing bottom-up approaches to climate change adaptation, but we argue that they should be distinguished in this context. Devolution can be broadly understood as the relocation of power, construed as capacity or authority in decision-making, from a center to local-level entities such as local governments or communities (Bardhan 2002; Fisher 1999). Decentralization generally refers to the transfer of power and resources - political, fiscal, or administrative - away from the central government to non-central government entities (Schneider 2003), which can occur with or without relocating the decision-making power (Bardhan 2002; Fisher 1999). While other definitions of decentralization include some degree 
of power transfer, it is understood that devolution represents a firmer and more institutionalized transfer of power to localities when compared to decentralization (Barrett 2015). Decentralization without devolution is sometimes referred to as "deconcentration," involving merely shifting the workloads from a central authority to local bureaucracies while decisionmaking power remains centralized (Regmi and Star 2014; Tacconi 2007).

While decentralization in the overall government structure is considered a promising approach to promote bottom-up climate change adaptation (Brockhaus and Kambiré 2009; Scanlon and Nobbe 2010), recent literature emphasizes that community-focused adaptation also requires devolved decision-making to the local level in an actual project setting (Regmi and Star 2014). This is because community participation processes alone do not guarantee that an externally financed adaptation project would be locally responsive. In many cases, community participation processes only engage community stakeholders as feedback providers to confirm a predetermined project design (UNDP 2014), and can fail to genuinely involve communities in adaptation interventions (Mikulewicz 2018; Sherman and Ford 2014). Apart from community participation, it is argued that an explicit transfer of decision-making power to the communities is required for them to truly determine the methods and goals of adaptation that build on their own knowledge, livelihood practices, and preferences (Dodman and Mitlin 2013; Kirkby et al. 2015; Regmi and Star 2014).

In the context of climate finance, there are calls for multilateral climate funds to move beyond the decentralization of implementation-related tasks and community consultation to devolve the actual decision-making power on project fund use to the local level (Bosma et al. 2018). This involves, for example, relocating funding approval functions, in addition to implementation and execution authorities, to NIEs and their EEs (Müller 2013), and having more downwardly accountable local actors, such as CBOs and local NGOs, to formally serve as EEs and partners of EEs (AFB 2008). Comparing decentralized and devolved systems for subnational allocation of domestic climate finance in Kenya, Barrett (2015) found that the devolved structures outperformed the decentralized ones in targeting adaptation finance resources at local vulnerable communities.

\section{Design for policy adoption and replicability}

Apart from being participatory and devolutionary, we argue that a community-focused adaptation project should also be designed from the onset to ensure the long-term adoption of adaptation actions and the replicability of benefits they deliver. Huq and Faulkner (2013) argue that such concern for time scale (i.e., the ensured community climate resilience after the project has finished), and geographical scale (i.e., the replicability of resilience beyond immediate project boundaries), are key design features that enable CBA initiatives to deliver "transformed resilience" results.

Apart from stressing the importance of capacity building for climate-vulnerable local communities (Kirkby et al. 2017), the recent CBA literature also calls for community adaptation initiatives to maximize their long-term adaptation benefits and replicability through two types of mainstreaming (Huq and Faulkner 2013; McNamara and Buggy 2017; Reid and Huq 2014). First, policy mainstreaming generally refers to the integration of adaptation objectives into government policymaking (Klein 2010; Uittenbroek et al. 2013). An example of CBA policy mainstreaming is when community adaptation concerns and practices are vertically integrated into policy processes above the community level (McNamara and Buggy 2017; Regmi and Star 2014; Saito 2013). The policy mainstreaming of community-based approaches, which is sometimes referred to as "scaling-up" (Fenton et al. 2014; Huq and Faulkner 2013), reflects the institutionalization of these approaches into long-term structures beyond a project's life. Second, geographical mainstreaming, or "scaling out," concerns the horizontal expansion of successful community adaptation practices to different locations (Huq and Faulkner 2013), leading to a replication of community best practices at a larger scale. While the two types of mainstreaming processes can and often take place in a complementary manner, they should be conceptually distinguished as the knowledge, skills, and enabling conditions required may differ (Huq and Faulkner 2013).

\section{Data and methods}

\section{Sample}

We make use of the publicly available database of AF projects for analysis. As of May 2017, the AF approved 63 projects from 53 countries, comprising 41 indirect-access projects and 22 direct-access projects (see Supplementary material 1). All AF projects have approved proposal documents which follow the same standardized template and contain detailed project information (see Supplementary material 2). This facilitates a systematic comparison across projects and components (Ford and Berrang-Ford 2016).

\section{Operational indicators for assessment}

\section{Indicator of financial investment at the community level}

As discussed in "Conceptual framework," community-level project activities are defined as project activities that generate direct adaptation benefits to, as well as build capacity of, 
groups of households, villages, communes, neighborhoods, and settlements in climate-vulnerable locations. To operationalize the tracking of financing bound for these activities within a given AF project, we use the granular approach of the climate finance tracking methodology jointly developed by multilateral development banks to identify project components and sub-components that invest in the community-level activities and track the budget attached to them (Inter-American Development Bank (IADB), World Bank (WB), European Bank for Reconstruction (EBRD), (first), European Investment Bank (EIB), Inter-American Investment Corporation (IIC), African Development Bank (AfDB), and Asian Development Bank (ADB) 2017). We exclude project administration fees charged by AF implementing entities to identify the true fraction reaching community actors. An AF project that invests more in activities with direct adaptation benefits to local communities as a percentage of the total project budget (indicator F1) is considered more community -focused (Table 1).

\section{Community participation indicators}

We propose four indicators to operationalize the assessment of community participation in AF projects (Table 1). The first two indicators assess the level of participation of community-level stakeholders-defined as community members, community leaders, community groups, CBOs and local resource persons - in the design and implementation of each AF project. The latter two indicators assess if each project exhibits efficiency gains from community participation. We do not include indicators to assess the empowerment effect of participation as this would require a longer time horizon and an in-depth analysis which is beyond the scope of this paper.

The first two indicators for the level of community participation are as follows: (P1) the type of stakeholder participation, defined as self-mobilization, partnership, and consultation and (P2) the number of roles played by community stakeholders throughout the project cycle, with the potential nine roles comprising baseline development, vulnerability and adaptation assessment, project identification and proposal development, project implementation, support and outreach to local project participants, technical support and institutional support, monitoring and evaluation, capacity development, and lesson distillation and documentation. A project is considered to have a higher level of community participation if community-level stakeholders are consulted during the project design phase in a way that more resembles self-mobilization, and if they are involved in a higher number of roles throughout the project cycle.

The two indicators for efficiency gains from participation are as follows: (P3) the dimension of climate vulnerability of project beneficiaries, which refers

Table 1 Summary of dimensions, indicators and measurements of community-focused adaptation

\begin{tabular}{|c|c|c|c|}
\hline Dimension & Indicator & Indicator description & Measurement \\
\hline $\begin{array}{l}\text { 1. Financial investment at } \\
\text { the community level }\end{array}$ & $\mathrm{F} 1$ & $\begin{array}{l}\text { Budget for project activities that generate direct adaptation } \\
\text { benefits to community-level beneficiaries }\end{array}$ & $\begin{array}{l}\text { Community-level project budget/total project } \\
\text { budget (\%) } \\
\text { Conversion of \% into scores: high (3), medium (2), } \\
\text { and low (1) }\end{array}$ \\
\hline \multirow{5}{*}{$\begin{array}{l}\text { 2. Community } \\
\text { participation }\end{array}$} & \multicolumn{3}{|c|}{ Level of community participation } \\
\hline & $\mathrm{P} 1$ & $\begin{array}{l}\text { Type of public participation of community-level stake- } \\
\text { holders during project design }\end{array}$ & $\begin{array}{l}\text { Self-mobilization }(\text { score }=3) \text {; partnership } \\
\quad(\text { score }=2) \text {; consultation }(\text { score }=1)\end{array}$ \\
\hline & $\begin{array}{l}\text { P2 } \\
\text { Efficiency }\end{array}$ & $\begin{array}{l}\text { Roles performed by community-level stakeholders } \\
\text { throughout project cycle } \\
\text { gains from community participation }\end{array}$ & Number of roles (1-9) \\
\hline & P3 & Dimensions of vulnerability of project beneficiaries & Number of dimensions $(1-7)$ \\
\hline & $\mathrm{P} 4$ & $\begin{array}{l}\text { Sub-categories of beneficiaries within each dimension of } \\
\text { vulnerability }\end{array}$ & Number of sub-categories (1-25) \\
\hline \multirow[t]{3}{*}{$\begin{array}{l}\text { 3. Devolved } \\
\text { decision-making }\end{array}$} & D1 & Type of organizations that serve as project EE & $\begin{array}{l}\text { International }(\text { score }=0) \text {; national }(\text { score }=0) \\
\text { sub-national }(\text { score }=1) \text {; local }(\text { score }=2)\end{array}$ \\
\hline & D2 & Type of organizations that serve as partners of EE & $\begin{array}{l}\text { International }(\text { score }=0) \text {; national }(\text { score }=0) \\
\quad \text { sub-national }(\text { score }=1) \text {; local }(\text { score }=2)\end{array}$ \\
\hline & D3 & $\begin{array}{l}\text { Mechanisms to allow local decision-making on funding } \\
\text { approvals and adaptation choices }\end{array}$ & Yes (1); no (0) \\
\hline \multirow{2}{*}{$\begin{array}{l}\text { 4. Design for policy } \\
\text { adoption and } \\
\text { replicability }\end{array}$} & M1 & $\begin{array}{l}\text { Level of policy mainstreaming of community-level project } \\
\text { activities }\end{array}$ & Yes (1); no (0) \\
\hline & M2 & $\begin{array}{l}\text { Level of geographical mainstreaming of community-level } \\
\text { project activities }\end{array}$ & $\begin{array}{l}\text { Yes - action case (2); yes - intention case (1); No } \\
(0)\end{array}$ \\
\hline
\end{tabular}


to the biophysical and socioeconomic characteristics (i.e., livelihood sources, age, economic status, gender, health status, location and geography, and social status) that make a community and its members vulnerable to climate change; and (P4) the sub-categories of beneficiaries (e.g., women, elderly, ethnic minorities, disabled, landless laborer, single-headed households) within each dimension of vulnerability (see Supplementary material 3). While the indicator P3 reflects the diversity of lens used to identify sources of climate vulnerability, the indicator P4 reflects the higher inclusivity in project design. For example, a project that deals with livelihood source-related climate vulnerability, such as crop production, could identify different sub-categories of beneficiaries, such as female, elderly, and ethnic minority farmers, to tailor adaptation activities to match each sub-group's differentiated needs. In this paper, we assume that a project that targets a higher number of vulnerability dimensions and sub-categories of beneficiaries is more inclusive, reflecting the efficiency gains from the project proponent having solicited the diverse adaptation priorities from the community stakeholders themselves.

Finally, we consider a project to be more participatory overall, if it exhibits both a higher level of community participation during project design and implementation, as well as higher efficiency gains from such participation.

\section{Devolved decision-making indicators}

We use three indicators to operationalize the assessment of the level of devolved decision-making in AF projects as follows: (D1) the type of organizations that serve as EEs, using a typology of international, national, sub-national and community/local organizations; (D2) the type of organization that EEs partner with, using the same organizational typology as the indicator D1; and (D3) the existence of mechanisms within a given project design that enable local decision-making on funding approvals and adaptation choices. An example is a small grant facility, which devolves local decision-making on funding approvals to the grantees. Another example is a call for proposals from local communities, which solicits adaptation choices directly from the communities, while the decision-making on funding approvals remains with the AF. However, an AF project that involves a call for proposals is still more devolved than ones without. The AF framework allows for both the partnership with local organizations and the use of mechanisms for local decision-making. Whether and how much each project uses both is the decision of the NIE and MIE/RIE. For this paper, a project is considered more devolutionary if it involves a higher number of local organizations, such as CBOs and local NGOs, as EEs and EE partners, and uses a higher number of mechanisms for local decision-making (Table 1).

\section{Indicators for design for policy adoption and replicability}

We use the level of policy mainstreaming of community-level project activities (M1) to measure the concern in project design for policy adoption, and the level of geographical mainstreaming of these activities (M2) to measure the concern for replicability. For geographical replication, we also differentiate between the action cases, whereby concrete replication activities already take place within the current AF project, and the intention cases, which indicate a recognition of the need for replication but such action has not yet taken place. An action case is considered to represent a clearer plan for replication than an intension case (Table 1). A project which mainstreams communitylevel adaptation with policies and makes a clearer plan for geographical replication is considered to exhibit more design for policy adoption and replicability.

\section{Systematic content analysis}

Guided by the framework in "Conceptual framework," we combine deductive and inductive strategies to develop a coding system to systematically review the content of $63 \mathrm{AF}$ project documents for all indicators in Table 1 .

For the level of financial investment at the community level (F1), we first look for activities that directly target groups of households, villages, communes, neighborhoods, and settlements in climate-vulnerable locations. Once these activities are identified in the project documents, we extract the budget bound for them from each document based on the approach discussed in "Indicator of financial investment at the community level," and then calculate the community-level budget as a percentage of total project budget for the 63 projects.

For the indicators of community participation (P1-P4), devolved decision-making (D1-D3), and design for longterm adoption and replicability (M1-M2), we first consult the literature to identify relevant categories and subcategories and turn them into a preliminary set of codes for each indicator. For example, we integrate insights from the social vulnerability literature, which focuses on local-scale, bottom-up assessments of socioeconomic drivers of both vulnerability to climate change and responses to its impacts (Bohle et al. 1994; Mearns and Norton 2010; Noble et al. 2014), to define the seven categories to code the dimensions of climate vulnerability faced by community-level project beneficiaries: economic status, gender, age, social status, health status, livelihood source, and location and geography. We then test these codes with a sample of six AF project documents, resulting in incorporation of new codes emerging from the data. To extract information for every code, we review 
the structure of the AF project proposal template and identify sections with relevant information. To ensure that relevant information outside the pre-identified sections is also captured, we conduct a general search of the documents with relevant key words drawn from both the literature and a review of sample project documents (see Supplementary material 3 for more details). We analyze the coding results using Atlas.ti 7. We use the CodesPrimary Documents Table function to extract coded information for all indicators, except the indicator P4 where we use the Code-Co-occurrence Table. We tabulate the results for every indicator by access modality to assess the differences between direct-access and indirect-access projects.

\section{Limitations}

Given the study's data and methodology, some limitations should be noted. First, it is a systematic assessment of project proposals which represent how the projects are designed but do not capture changes during project implementation or project outcomes. As more projects mature, future research could analyze project evaluation documents and conduct in-depth case studies to assess the differences between direct-access and indirect-access projects in practice.

Second, the use of project design documents as the main data source means that community level perspectives are missing. It is recognized that community participation and devolved-decision making cannot be fully captured by analyzing project documents, and that the indicators used in this study do not reflect the differences in power that define whether we can consider community participation and decision-making processes equitable. Further in-depth study of existing or recently completed projects on the ground will complement this study to shed more lights in this aspect.

Third, the quality of project documents varies. While some projects provide comprehensive information with well-crafted texts, others are less extensive and at times less eloquently written. MIEs and RIEs are likely to be more adept in writing project proposals that meet AF criteria as well as international discourses on participation than NIEs. This could have resulted in systematic overreporting by MIEs and RIEs and underreporting by NIEs, especially those less familiar with project proposal preparation. However, this risk is mitigated by the fact that all the project proposals follow similar guidelines, ensuring that the same minimum extent of information is covered by each proposal. The inclusion of 63 projects in the analysis also ensures that our results are based on a relatively large sample of documents, thus mitigating the potential effects of varying document quality.

\section{Results}

\section{Financial investment at the community level}

As of May 2017, the AF had committed a grand total of US $\$ 416.1$ million of grant financing to 63 adaptation projects (22 direct-access and 41 indirect-access projects). The projects are distributed relatively equally between developing countries from the Asia-Pacific (23), African (20) and Latin American and Caribbean (19) regions, with only one project in Eastern Europe (Georgia). With an investment cap of US $\$ 10$ million per country, the average size of a project (including execution and management fees) is US\$6.6. million; direct-access projects have an average size of US $\$ 6.8$ million and indirect-access-projects of US $\$ 6.5$ million. The biggest project (Mongolia) received US\$9.99 million, while the smallest project (India) received US $\$ 0.69$ million, both of which are direct-access projects. After excluding the execution and management fees from the total amount of project financing, we find that the average size (the total component cost only) of a direct-access project is US\$6 million, compared to US\$5.5 million for an indirect-access project. This suggests that, on average, direct access projects have lower combined execution and management fees $(12 \%)$ than indirect-access projects (15\%).

For the indicator F1, we find that the level of financial investment in at the community level is higher in direct-access projects compared to indirect-access projects. On average, direct-access projects invest $77.2 \%$ of project budget from the total component cost at the community level compared to $69.7 \%$ in indirect-access projects. Three direct-access projects invest $100 \%$ of their total component cost in community-level activities compared to two indirect-access projects.

\section{Qualitative characteristics of locally driven adaptation at the community level}

\section{Community participation}

Overall, we find that direct-access projects are more participatory than indirect-access projects, due to a higher level of community participation, measured by the indicators $\mathrm{P} 1$ and $\mathrm{P} 2$, and higher efficiency gains from community participation, measured by the indicators $\mathrm{P} 3$ and $\mathrm{P} 4$.

For the type of public participation during project design (P1), we find no projects reporting their consultative process in a way that is consistent with self-mobilization. The most dominant form of public participation reported by most projects in both modalities - comprising $100 \%$ of the indirect-access projects and $90 \%$ of direct-access projects - was "consultation." However, we find that $10 \%$ of direct-access projects reported their consultative process in a way that is consistent with partnership, while none of indirect-access projects did. 
When comparing the number of roles played by community-level stakeholders throughout the project cycle (P2), we find that on average these stakeholders play four roles per project in both modalities. However, when each role is compared between modalities, a higher proportion of direct-access projects involve community-level stakeholders across the roles (Fig. 1). The biggest difference is found in monitoring and evaluation, whereby $82 \%$ of direct-access projects reporting the involvement of community-level stakeholders compared to only $41 \%$ of indirect-access projects. This is followed by the difference in community involvement in vulnerability and adaptation assessment, whereby $86 \%$ of direct-access projects reporting the involvement of community-level stakeholders compared to only $63 \%$ of indirect-access projects (Fig. 1).

As the first indicator for efficiency gains from community participation (P3), we find that five out of seven key dimensions of climate vulnerability are addressed by more direct-access projects than indirect-access projects. These five dimensions are livelihood sources, age, economic status, gender and social status. Only two dimensions of vulnerability - health status and location and geographyare covered by more indirect-access projects (Fig. 2).

As the second indicator for efficiency gains from community participation ( $\mathrm{P} 4)$, we find that on average direct-access projects target six sub-categories of beneficiaries per project, while indirect-access projects target five sub-categories per project. We interpret this higher number of sub-categories of beneficiaries to reflect more inclusivity in the project design, suggesting more efficiency gains from community participation. However, in terms of the dominant sub-categories of project beneficiaries, we find that the poor, smallholder farmers, women, children, and youth are the most targeted sub-categories in both access modalities.

\section{Devolved decision-making}

Overall, we find that direct-access projects are more devolutionary than indirect-access projects, as measured by the three indicators for devolved decision-making. While national-level organizations are the most common EEs for both direct-access and indirect-access projects, a higher proportion of directaccess projects are executed by sub-national and local organizations (D1); we find no indirect-access project with local organizations officially assigned as its EEs (Fig. 3a). The EEs of more direct-access projects $(82 \%)$ than indirectaccess projects $(71 \%)$ also partner with local organizations, while the EEs of more indirect-access projects partner with national and sub-national organizations than direct-access projects (D2) (Fig. 3b). We also find that $27 \%$ of directaccess projects employ mechanisms to allow local decisionmaking on funding approvals and adaptation choices (D3) compared with $17 \%$ in indirect-asses projects. In terms of the type of mechanisms used, direct-access projects operationalize more small grant facilities, while indirectaccess projects use more calls for adaptation proposals from local stakeholders including communities and CBOs.

\section{Design for policy adoption and replicability}

We find no difference between direct-access and indirect-access projects with regard to how they are designed to promote the policy adoption and replicability of community adaptation actions through policy and geographical mainstreaming.

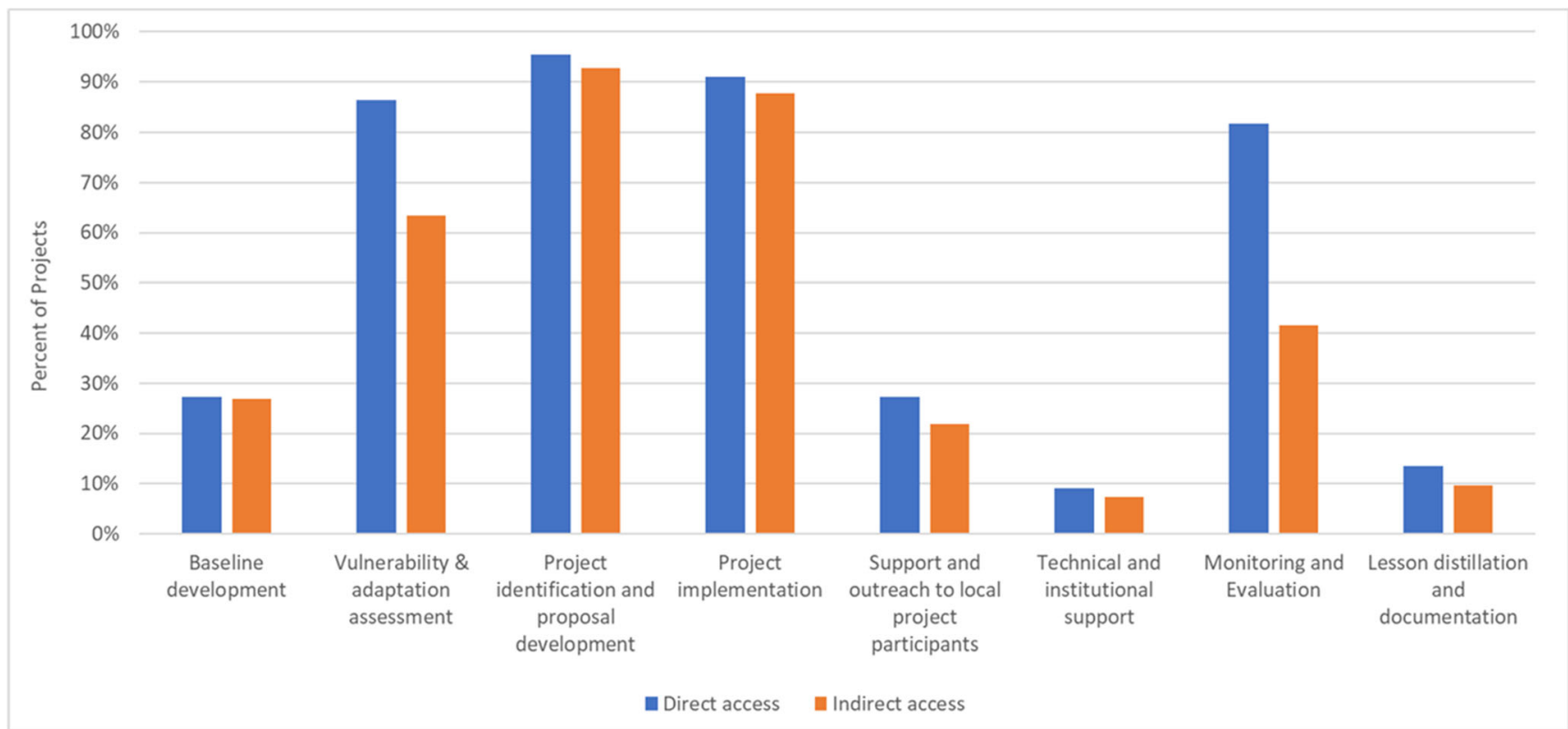

Fig. 1 Roles played by community-level stakeholders throughout project cycle 
Fig. 2 Biophysical and socioeconomic dimensions of climate vulnerability addressed by $\mathrm{AF}$ projects

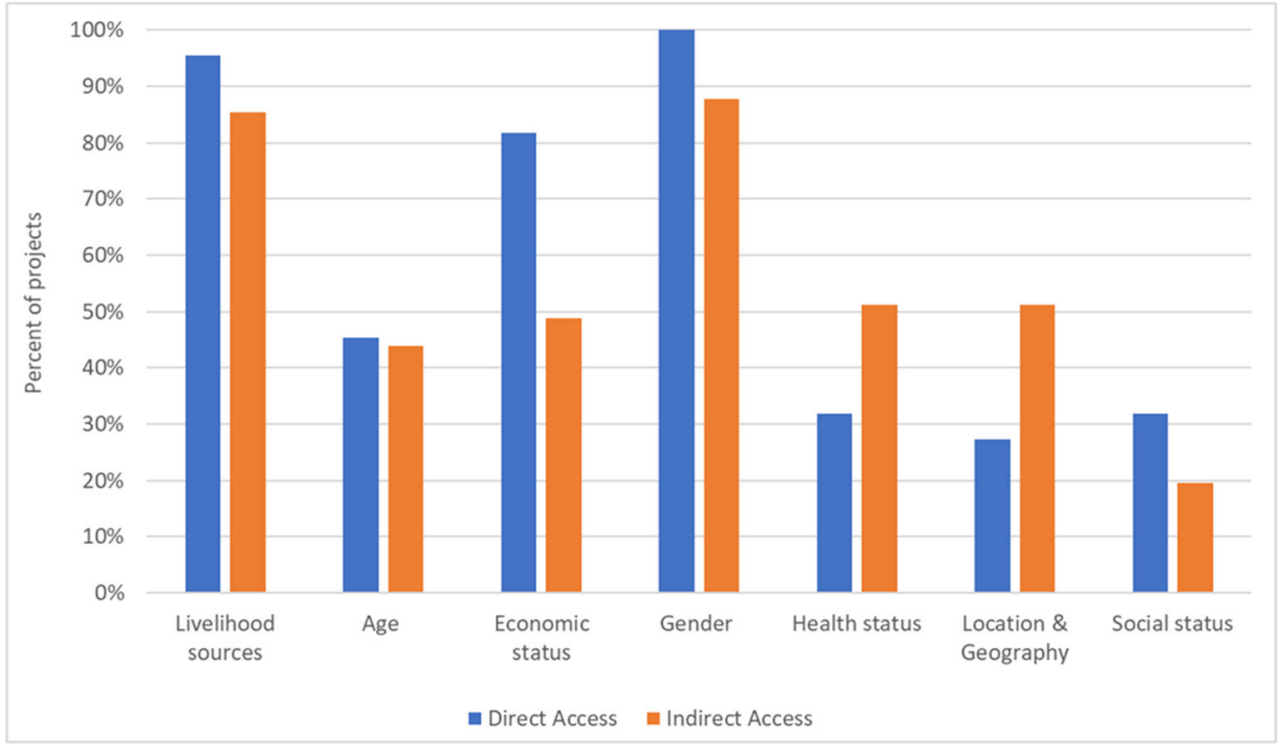

All project proposals reported the integration of the financed community adaptation activities with some form of national, regional, and/or sectoral policies (M1). While we find that the design for geographical mainstreaming (M2) varies between both access modalities, the overall results show a similar pattern; $68 \%$ of direct-access projects are the intention cases compared to $64 \%$ of indirect-access projects, and $37 \%$ of indirect-access projects are action cases compared to $31 \%$ of direct-access projects.

\section{Discussion}

Much of the current climate finance literature focuses on the AF's effort to introduce direct access and how the modality changes recipient country-fund relationships vis-à-vis indirect access. Our findings move beyond this emphasis to build an initial understanding of the design characteristics of adaptation projects under both access modalities. They also offer a glimpse of how much national and international implementing entities of the $\mathrm{AF}$ have directed financial resources towards the local communities, while engaging subnational institutions and local stakeholders in the process. These findings complement the growing research that systematically analyzes the portfolios of international climate funds to understand how global and local processes interact to shape adaptation processes in developing countries (Biagini et al. 2014; Conevska et al. 2018; Remling and Persson 2015). By establishing empirical knowledge from the AF's operationalization of the two modalities, which arguably represent different models of climate finance governance, the paper's findings inform the policy discourse on how to improve institutional arrangements of international climate finance to support local adaptation (Bird 2014; Brown et al. 2013; Nakhooda et al. 2014). The empirical findings here could also inform future theory building on the role of a decentralized climate finance governance model such as the direct-access modality in shaping local climate actions.
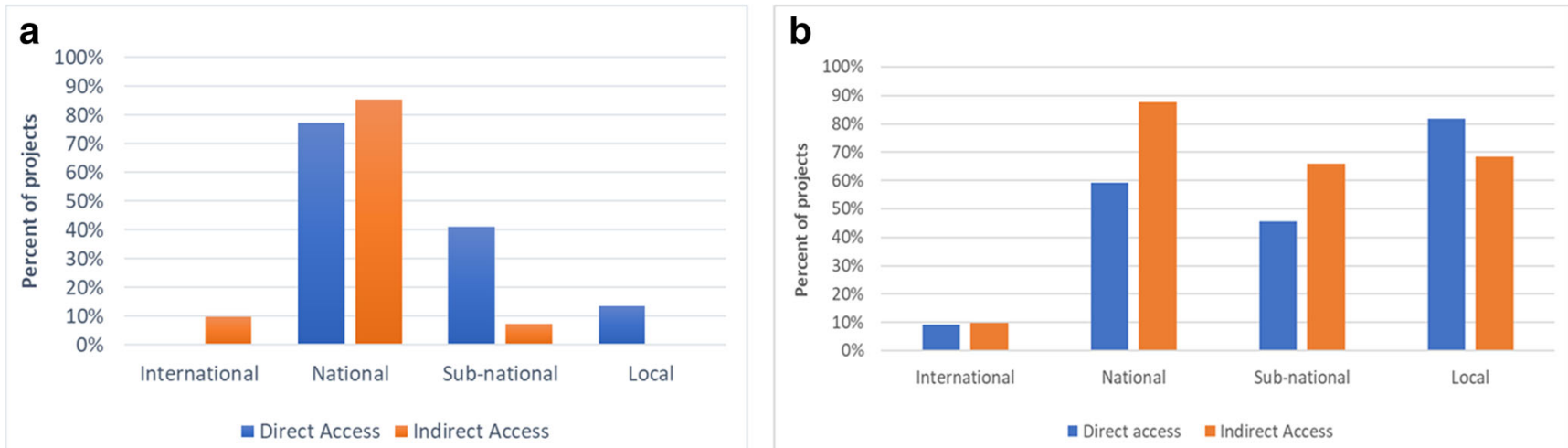

Fig. 3 a Type of organizations that serve as EEs of AF projects. A project can have multiple EEs. b Type of organizations that EEs of AF projects partner with. An EE can have multiple partners 
The findings on community participation provide insights on how climate vulnerability is framed in developing countries. The main vulnerable groups we find being targeted by the AF projects in both access modalities are rural populations, particularly smallholder farmers, women, youth and the elderly, which reflect the same pattern as seen in the Intended Nationally Determined Contributions (UNFCCC 2015). These findings differ from those of Remling and Persson (2015), who analyzed 27 AF project proposals approved by the end of 2012 and found limited focus on social aspects of vulnerabilities such as gender and ethnicity. On the contrary, we find that women are one of the most commonly targeted beneficiaries. Projects from Ecuador, Guatemala, Belize, Nepal, India, Lao PDR, Honduras, Panama, and Paraguay also explicitly target marginalized groups including ethnic minorities, indigenous populations and low-caste communities. These different results could be driven by the different content analysis methodology. It could also reflect post-2012 changes in AF policies, particularly the new requirement that proposals strongly consider gender equality and women empowerment (TANGO International and ODI 2015).

Our results on devolved decision-making provide some initial support to an expectation that the direct-access modality could promote subnational devolution of climate finance decision-making (Bosma et al. 2018). Devolution is broadly defined in this paper as the presence of more subnational and local organizations, as well as the transfer of decision-making power on funding approvals and adaptation choices to them, within the formal decision-making structure of an internationally financed adaptation project. Future research could examine if this process-based devolution fully reflects the theoretical construct and performance expectations of a devolved structure, or whether it is more in line with decentralization or deconcentration, and what are the implications of these different governance variants for bottom-up climate change adaptation.

Finally, our findings on the design for the policy adoption and replicability of community adaptation actions do not lend support to some of the literature that expects the direct-access modality to promote more policy and geographical mainstreaming of community-adaption approaches when compared to indirect access (Craeynest et al. 2010). Two factors should be considered here. First, the AF requires that all projects report clear linkages to national and subnational policies. In each country, the AF's designated national authority also has to endorse a project proposal, a process which is similar in both access modalities. These requirements ensure that all AF projects are integrated with national policy processes. Second, while NIEs are well-placed to promote policy integration, MIEs can also do so in indirect-access projects. For example, the United Nations Development Programme (UNDP) had played an active role in supporting the National Adaptation Programme of Action (NAPA) in many developing countries while also serving as a MIE of the AF. These dual roles have contributed to the strong integration of the UNDP-implemented AF projects with national adaptation priorities formulated in NAPAs (Schäfer et al. 2014). In some countries, it is the process of AF project preparation itself that catalyzes adaptation policy mainstreaming. For example, the process of developing the UNDP-implemented AF project in Honduras helped initiate the integration of adaptation objectives into the country's national development and water policies (TANGO International and ODI 2015).

While providing a useful insight about AF projects, it is recognized that the binary mainstreaming indicators used in this study do not capture any qualitative differences in the mainstreaming processes between countries, or whether and how the processes evolve during project implementation. Understanding these dynamics and how they unfold over time requires future research with an in-depth case study approach. In addition, it is recognized that national-level government actors cannot always be assumed to represent the interests of their populations, and that national policies to promote climate resilience, especially those designed by technocratic elites, can end up favoring elites (such as landowners), while excluding the most vulnerable (such as the landless, and displaced peasants) (Sovacool et al. 2019). These political economy issues need to be taken into account in fully understanding the interplay between policy mainstreaming and the sustainability of community level adaptation actions, and more broadly, in analyzing the relationship between state and citizens in shaping the local use of international adaptation finance.

Two considerations should inform the interpretation of the paper's findings. First, the paper's objective is descriptive which means that we cannot attribute the observed differences between direct-access and indirect-access projects solely to the modalities. While the modalities could play a role for the financial, participatory and devolutionary differences between direct-access and indirect-access projects, they are likely to do so in conjunction with other potential contributing factors, such as the experience of extreme weather events motivating countries to apply for financing to protect vulnerable localities (Conevska et al. 2018), the balance between top-down and bottom-up approaches in recipient countries' government structure and other enabling conditions for community mobilization such as the governance of civil society. Explaining the causation requires further research that aggregates all indicators used in this study to determine and compare the overall level of community focus of AF projects, and uses a different research design, such as a qualitative comparative analysis (QCA), to determine the conditions that explain the occurrence and non-occurrence of the community focus outcome. (See such QCA analysis and its results in Manuamorn et al. (2020)). Second, our research intention and findings are not normative in the sense that we do not imply that one modality 
is better than the other. Multiple modalities are going to be needed to address the range of climate financing needs and readiness of developing countries and could co-exist within a single country (Müller and Pizer 2014). Choosing an access modality is likely a country's decision shaped by context, capacities, and preference (Biesbroek et al. 2018).

\section{Conclusion}

The paper assesses if direct-access and indirect-access adaptation projects are different in terms of their focus on vulnerable local communities using the $\mathrm{AF}$ as the case study. We propose a new framework to assess the level of community focus in adaptation projects, using a combination of financial, participatory, devolutionary, and design for long term adoption and replicability criteria. We find that direct-access projects are more community-focused than indirect-access projects because they exhibit higher community-oriented financial, participatory, and devolutionary characteristics. We find no difference between the direct-access and indirect-access projects with regard to how they are designed to promote the policy adoption and replicability of community adaptation actions through policy and geographical mainstreaming.

Recognizing that our findings are based on project documents that provide partial views, we draw the following initial observations that could have important policy implications for international climate funds and developing countries. While we find that direct-access projects are on average more communityfocused than indirect-access projects, community-focused adaptation projects are present under both access modalities to the $\mathrm{AF}$, and many MIEs that implement indirect-access projects also engage sub-national institutions and local stakeholders as actively as, or even more than, some NIEs. This suggests that while the direct-access modality has the potential to enhance climate finance outcomes at the community level, this potential does not necessarily and automatically materialize in all cases. On the other hand, while some indirect-access projects perform well on financial investment at the community level, community participation, and devolved decision making, many show gaps. This finding should serve to remind MIEs to take extra care in improving project design in these aspects.

To accelerate the delivery of international adaptation finance to local level, policy could aim to build capacity of both direct-access and indirect-access entities to further engage other subnational and local stakeholders in fund use. Capacity building for community members as well as organizations that support them such as CBOs is also essential to ensure that they can meaningfully participate in the identification and design of internationally financed adaptation projects. At the same time, it is important to recognize that capacity building alone is not a panacea, especially if implemented without adequate consideration of differentiated dimensions of vulnerability thus adaptation needs, and of the unequal initial capacities and access to resources within a community. Beyond capacity building, community stakeholders also need to be empowered to meaningfully participate as decision makers and beneficiaries in both access modalities by more active use of concrete mechanisms such as a small grant facility and a call for proposals from local communities as discussed in this paper. Finally, as NIEs, MIEs and RIEs of the AF have gained experience and lessons learned from engaging sub-national stakeholders during project design and implementation, more knowledge sharing among them should be facilitated, with a view to inform the design of future internationally financed adaptation projects under different country contexts.

Acknowledgments The authors are grateful for valuable comments received from all participants at the seminars of the Dual-Career Ph.D. Program $\left(\mathrm{GPAC}^{2}\right)$ at the Maastricht Graduate School of Governance (MGSoG), UNU-MERIT, Maastricht University, The Netherlands.

\section{Compliance with ethical standards}

Conflict of interest The authors declare that they have no conflict of interest.

Open Access This article is licensed under a Creative Commons Attribution 4.0 International License, which permits use, sharing, adaptation, distribution and reproduction in any medium or format, as long as you give appropriate credit to the original author(s) and the source, provide a link to the Creative Commons licence, and indicate if changes were made. The images or other third party material in this article are included in the article's Creative Commons licence, unless indicated otherwise in a credit line to the material. If material is not included in the article's Creative Commons licence and your intended use is not permitted by statutory regulation or exceeds the permitted use, you will need to obtain permission directly from the copyright holder. To view a copy of this licence, visit http://creativecommons.org/licenses/by/4.0/.

\section{References}

Adaptation Fund (2012) The Adaptation Fund and direct access: supporting developing countries in undertaking concrete measures to adapt to the adverse effects of climate change. Adaptation Fund Board Secretariat, Washington, DC. http://www.adaptation-fund. org/wp-content/uploads/2015/03/DirectAccessMemo29_Oct 2012. pdf. Accessed 9 Sept 2018

Adaptation Fund (2013) Enhancing climate resilience of rural communities living in protected areas of Cambodia [project document]. Adaptation Fund Board Secretariat. https://www.adaptation-fund. org/project/enhancing-climate-resilience-of-rural-communitiesliving-in-protected-areas-of-cambodia/. Accessed 4 Jun 2019

Adaptation Fund (2014) Reducing vulnerability to climate change in North West Rwanda through community based adaptation [Project document]. Adaptation Fund Board Secretariat. https://www. adaptation-fund.org/project/reducing-vulnerability-to-climatechange-in-north-west-rwanda-through-community-basedadaptation/. Accessed 4 Jun 2019 
AFB (2008) Roles and responsibilities of implementing and executing entities. Adaptation Fund Board First meeting Bonn, March 26-28, 2008 (AFB/B.1/6). Adaptation Fund Board. https://www. adaptation-fund.org/wp-content/uploads/2015/01/AFB.B.1.6 Roles_and Responsibilities_of the IE_and EE_February_29, 2008.pdf. Accessed 23 Oct 2017

Agrawal A (2008) The role of local institutions in adaptation to climate change (Working Paper No. 69128). The World Bank, Washington, DC. https://openknowledge.worldbank.org/bitstream/handle/ 10986/28274/691280WP0P11290utions0in0adaptation.pdf? sequence $=1$ \&isAllowed $=y$. Accessed 8 Sept 2018

Ayers J, Forsyth T (2009) Community-based adaptation to climate change. Environ Sci Policy Sustain Dev 51(4):22-31. https://doi. org/10.3200/ENV.51.4.22-31

Bardhan P (2002) Decentralization of governance and development. J Econ Perspect 16(4):185-205. https://doi.org/10.1257/ 089533002320951037

Barrett S (2015) Subnational adaptation finance allocation: comparing decentralized and devolved political institutions in Kenya. Glob Environ Politics 15(3):118-139. https://doi.org/10.1162/GLEP a 00314

Biagini B, Bierbaum R, Stults M, Dobardzic S, McNeeley SM (2014) A typology of adaptation actions: a global look at climate adaptation actions financed through the global environment facility. Glob Environ Chang 25:97-108. https://doi.org/10.1016/j.gloenvcha. 2014.01.003

Biesbroek R, Lesnikowski A, Ford JD, Berrang-Ford L, Vink M (2018) Do administrative traditions matter for climate change adaptation policy? A comparative analysis of 32 high-income countries. Rev Policy Res 35(6):881-906. https://doi.org/10.1002/wcc.548

Bird N (2014) Improving access to international climate finance within sub-Saharan Africa [ODI working paper]. Overseas Development Institute. https://www.odi.org/sites/odi.org.uk/files/odi-assets/ publications-opinion-files/9142.pdf. Accessed 9 Aug 2017

Bird N, Billett S, Colón C (2011) Direct access to climate finance: experiences and lessons learned. United Nations Development Programme. https://www.odi.org/publications/6150-direct-accessclimate-finance-experiences-lessons-learned. Accessed 6 Oct 2016

Bohle HG, Downing TE, Watts MJ (1994) Climate change and social vulnerability: toward a sociology and geography of food insecurity. Glob Environ Chang 4(1):37-48. https://doi.org/10.1016/09593780(94)90020-5

Bosma M, de Hon M, Douma A, Robben D, Chhetri RP, et al (2018) Local actors ready to act: six proposals to improve their access to the green climate fund. Both ENDS; Heinrich Böll Sitftung North America; Aksi! for gender, social and ecological justice; Prakriti Resources Centre. https://us.boell.org/2018/06/13/local-actorsready-act-six-proposals-improve-their-access-green-climate-fund. Accessed 3 Sept 2018

Brockhaus M, Kambiré H (2009) Decentralization: a window of opportunity for successful adaptation to climate change. In: Adger WN, Lorenzoni I (eds) Adapting to climate change: thresholds, values, governance (pp. 399-416). Cambridge University Press

Brown J, Bird N, Schalatek L (2010) Direct access to the adaptation fund: realising the potential of national implementing entities. Overseas Development Institute. http://www.boell.de/sites/default/files/ assets/boell.de/images/download_de/2010-11-23_Direct_Access_ to the_Adaptation_Fund.pdf. Accessed 5 Jun 2016

Brown L, Polycarp C, Spearman M (2013) Within reach: strengthening country ownership and accountability in accessing climate finance. World Resources Institute. https://www.wri.org/publication/ ownership-and-accountability-in-climate-finance. Accessed 3 Sept 2018

Buggy L, McNamara KE (2016) The need to reinterpret "community" for climate change adaptation: a case study of Pele Island, Vanuatu.
Clim Dev 8(3):270-280. https://doi.org/10.1080/17565529.2015. 1041445

Carter T, Jones RN, Lu X, Bhadwal S, Conde C et al (2007) In: Parry ML, Canziani OF, Palutikof JP, van der Linden PJ, Hanson CE (eds) New assessment methods and the characterisation of future conditions. Climate change 2007: impacts, adaptation and vulnerability. Contribution of Working Group II to the Fourth Assessment Report of the Intergovernmental Panel on Climate Change. Cambridge University Press, Cambridge, pp 133-171

Chambers R (1983) Rural development: putting the last first. Routledge

Chambers R (1994) Participatory rural appraisal (PRA): challenges, potentials and paradigm. World Dev 22(10):1437-1454. https://doi. org/10.1016/0305-750X(94)90030-2

Cleaver F (1999) Paradoxes of participation: questioning participatory approaches to development. J Int Dev 11(4):597-612. https://doi. org/10.1002/(SICI)1099-1328(199906)11:4<597::AID-JID610>3. $0 . \mathrm{CO} ; 2-\mathrm{Q}$

Conde C, Lonsdale K, Nyong A, Aguilar I (2005) Engaging stakeholders in the adaptation process. Cambridge University Press, Cambridge http://www.adaptation-undp.org/sites/default/files/downloads/ adaptation_policy_frameworks_for_climate_change__developing_strategies_policies_and_measures_0.pdf\#page $=51$. Accessed 13 Jan 2017

Conevska A, Ford JD, Lesnikowski A, Harper S (2018) Adaptation financing for projects focused on food systems through the UNFCCC. Clim Pol:1-16. https://doi.org/10.1080/14693062.2018.1466682

Craeynest L, Gallagher L, Sharkey C (2010) Business as unusual. Direct access: giving power back to the poor? [discussion paper]. CIDSE

Dodman D, Mitlin D (2013) Challenges for community-based adaptation: discovering the potential for transformation. J Int Dev 25(5):640 659. https://doi.org/10.1002/jid.1772

Druce L, Grüning C, Menzel C (2013) Direct access to international climate finance and associated fiduciary standards [Paper]. Frankfurt School - UNEP Collaborating Centre for Climate \& Sustainable Energy Finance. http://fs-unep-centre.org/publications/ direct-access-international-climate-finance-and-associatedfiduciary-standards. Accessed 20 Nov 2015

Duus-Otterström G (2016) Allocating climate adaptation finance: examining three ethical arguments for recipient control. Int Environ Agreements Polit Law Econ 16(5):655-670. https://doi.org/10. 1007/s10784-015-9288-3

Fenton A, Gallagher D, Wright H, Huq S, Nyandiga C (2014) Up-scaling finance for community-based adaptation. Clim Dev 6(4, SI):388 397. https://doi.org/10.1080/17565529.2014.953902

Fenton A, Reid H, Wright H, Huq S (2015) Ten principles to help assess funding for local climate adaptation [IIED Briefing]. International Institute for Environment and Development. http://pubs.iied.org/ 17323IIED/. Accessed 6 Nov 2016

Few R, Brown K, Tompkins EL (2007) Public participation and climate change adaptation: avoiding the illusion of inclusion. Clim Pol 7(1): 46-59. https://doi.org/10.1080/14693062.2007.9685637

Fisher RJ (1999) Devolution and decentralization of forest management in Asia and the Pacific. Unasylva: Decentralization Devolution For 50(199):3-5. http://www.fao.org/3/x3030e/x3030e00.htm\# Contents

Ford JD, Berrang-Ford L (2016) The 4Cs of adaptation tracking: consistency, comparability, comprehensiveness, coherency. Mitig Adapt Strateg Glob Chang 21(6):839-859. https://doi.org/10.1007/ s11027-014-9627-7

Forsyth T (2013) Community-based adaptation: a review of past and future challenges. WIREs Clim Chang 4(5):439-446. https://doi. org/10.1002/wcc. 231

GCF (2015) "Additional Modalities that Further Enhance Direct Access: Terms of Reference for a Pilot Phase" Meeting of the Board 6-9 July 2015 Songdo, Republic of Korea Provisional Agenda item 10 (GCF/B.10/05). Green Climate Fund. https://www.greenclimate. 
fund/documents/20182/24952/GCF_B.10_05___Additional_ Modalities_that_Further_Enhance_Direct_Access_Terms_of Reference_for_a Pilot_Phase.pdf/409c098e-60c $\overline{2}-45 \mathrm{e} 9-8 \overline{\mathrm{b} e a-}$ 4b2dba371ce1. Accessed 23 Oct 2017

GCF (2018) Enhancing adaptive capacities of coastal communities, especially women, to cope with climate change induced salinity [Text]. Green Climate Fund. https://www.greenclimate.fund/ projects/fp069. Accessed 8 Sept 2018

Harmeling S, Kaloga AO (2010) Adaptation Fund under the KP: mature for concrete implementation of projects and direct access (European Capacity Building Initiative Policy Report). Germanwatch e.v. Bonn. https://af-network.org/4923. Accessed 2 Feb 2018

Harmeling S, Kaloga AO (2011) Understanding the political economy of the Adaptation Fund. IDS Bull-Inst Dev Stud 42(3):23-32. https:// doi.org/10.1111/j.1759-5436.2011.00219.x

Horstmann B (2011) Operationalizing the Adaptation Fund: challenges in allocating funds to the vulnerable. Clim Pol 11(4):1086-1096. https://doi.org/10.1080/14693062.2011.579392

Huq S, Faulkner L (2013) Taking effective community-based adaptation to scale: an assessment of the GEF small grants programme community-based adaptation project in Namibia (p 84). Global Environment Facility. https://www.thegef.org/sites/default/files/ publications/SGP_CBA_Project_in_Namibia_0.pdf. Accessed 23 Oct 2017

IIED (2014) Kathmandu declaration on financing local adaptation to climate change. International Institute for Environment and Development. http://pubs.iied.org/G03787/. Accessed 30 Sept 2016

Inter-American Development Bank (IADB), World Bank (WB), European Bank for Reconstruction (EBRD), (first), European Investment Bank (EIB), Inter-American Investment Corporation (IIC), African Development Bank (AfDB), \& Asian Development Bank (ADB) (2017) 2016 joint report on multilateral development banks' climate finance. Inter-American Development Bank. http:// publications.iadb.org/handle/11319/8505. Accessed 22 Oct 2017

Kepe T (1999) The problem of defining 'community': challenges for the land reform programme in rural South Africa. Dev South Afr 16(3): 415-433. https://doi.org/10.1080/03768359908440089

Kirkby P, Williams C, Huq S (2015) A brief overview of communitybased adaptation [briefing paper]. International Center for Climate Change and Development (ICCCAD) at at the Independent University, Bangladesh (IUB). http://eprints.utas.edu.au/22473/. Accessed 6 Oct 2016

Kirkby P, Williams C, Huq S (2017) Community-based adaptation (CBA): adding conceptual clarity to the approach, and establishing its principles and challenges. Climate and Development, 113. https://doi.org/10.1080/17565529.2017.1372265

Klein RJ (2010). Mainstreaming climate adaptation into development: A policy dilemma, in: Climate Governance and Development, Berlin Workshop Series. The World Bank, Washington, DC pp 1-157

Lasage R, Muis S, Sardella CSE, van Drunen MA, Verburg PH et al (2015) A stepwise, participatory approach to design and implement community based adaptation to drought in the Peruvian Andes. Sustainability 7(2):1742-1773. https://doi.org/10.3390/su7021742

Lebel L, Käkönen M, Dany V, Lebel P, Thuon T et al (2018) The framing and governance of climate change adaptation projects in Lao PDR and Cambodia. Int Environ Agreements Polit Law Econ 18(3):429446. https://doi.org/10.1007/s10784-018-9397-x

Mansuri G, Rao V (2003) Community-based and-driven development: a critical review (pp 1-39) [Working Paper]. World Bank. http://wbro. oxfordjournals.org/content/19/1/1.short. Accessed 17 Jan 2017

Manuamorn OP, Biesbroek R, Cebotari V (2020) What makes internationally-financed climate change adaptation projects focus on local communities? A configurational analysis of 30 Adaptation Fund projects. Glob Environ Chang 61: 102035. https://doi.org/10.1016/j.gloenvcha.2020.102035
Masullo I, Larsen G, Brown L, Dougherty-Choux L (2015) "Direct access" to climate finance: lessons learned by National Institutions. World Resources Institute. http://www.wri.org/publication/directaccess. Accessed 6 Oct 2016

McDonnell S (2019) Other dark sides of resilience: politics and power in community-based efforts to strengthen resilience. Anthropol Forum 30(1-2):55-72. https://doi.org/10.1080/00664677.2019.1647828

McNamara KE, Buggy L (2017) Community-based climate change adaptation: a review of academic literature. Local Environ 22(4):443460. https://doi.org/10.1080/13549839.2016.1216954

Mearns R, Norton A (2010) Social dimensions of climate change: equity and vulnerability in a warming world. The World Bank, Washington, DC

Mikulewicz M (2018) Politicizing vulnerability and adaptation: on the need to democratize local responses to climate impacts in developing countries. Clim Dev 10(1):18-34. https://doi.org/10.1080/ 17565529.2017.1304887

Müller B (2013) Enhanced (direct) access' through '(national) funding entities'-etymology and examples: information note on the green climate fund business model framework. The Oxford Institute for Energy Studies, University of Oxford. https://www.oxfordenergy. org/wpcms/wp-content/uploads/2013/05/Enhanced-Direct-AccessApril-2013.pdf. Accessed 27 July 2017

Müller B, Pizer W (2014) Devolved access modalities: lessons for the green climate Fund from existing practice (Working Paper NI WP 14-03). Duke University. https://nicholasinstitute.duke.edu/sites/ default/files/publications/devolved_access_modalities.pdf. Accessed 10 Aug 2017

Nakhooda S, Norman M, Barnard S, Watson C, Greenhill R, et al (2014) Climate finance: is it making a difference? A review of the effectiveness of Multilateral Climate Funds. Overseas Development Institute. http://www.odi.org/sites/odi.org.uk/files/odi-assets/ publications-opinion-files/9358.pdf. Accessed 6 Jun 2016

Noble IR, Huq S, Anokhin YA, Carmin J, Goudou D et al (2014) Adaptation needs and options. In: Field CB, Barros VR, Dokken DJ, Mach KJ, Mastrandrea MD, Bilir TE, Chatterjee M, Ebi KL, Estrada YO, Genova RC, Girma B, Kissel ES, Levy AN, MacCracken S, Mastrandrea PR, White LL (eds) Climate change 2014: impacts, adaptation, and vulnerability. Part A: Global and Sectoral Aspects. Contribution of Working Group II to the Fifth Assessment Report of the Intergovernmental Panel on Climate Change. Cambridge University Press, pp 833-868

Persson A, Remling E (2014) Equity and efficiency in adaptation finance: initial experiences of the adaptation Fund. Clim Pol 14(4):488-506. https://doi.org/10.1080/14693062.2013.879514

Piccolella A (2013) Participatory mapping for adaptation to climate change: the case of Boe Boe, Solomon Islands. Knowl Manag Dev J 9(1):24-36

Pretty JN, Guijt I, Thompson J, Scoones (1995) Participatory learning and action: a trainer's guide (IIED Participatory Methodology Series). International Institute for Environment and Development. http:// pubs.iied.org/6021IIED/. Accessed 16 Jan 2017

Reed MS (2008) Stakeholder participation for environmental management: a literature review. Biol Conserv 141(10):2417-2431. https://doi.org/10.1016/j.biocon.2008.07.014

Regmi BR, Star C (2014) Identifying operational mechanisms for mainstreaming community-based adaptation in Nepal. Clim Dev 6(4):306-317. https://doi.org/10.1080/17565529.2014.977760

Reid H, Huq S (2014) Mainstreaming community-based adaptation into national and local planning. Clim Dev 6(4):291-292. https://doi.org/ 10.1080/17565529.2014.973720

Reid H, Huq S, Murray LA (2010) Community champions: adapting to climate challenges. International Institute for Environment and Development (IIED). https://pubs.iied.org/pdfs/10028IIED.pdf. Accessed 10 Jun 2016 
Remling E, Persson A (2015) Who is adaptation for? Vulnerability and adaptation benefits in proposals approved by the UNFCCC Adaptation Fund. Clim Dev 7(1):16-34. https://doi.org/10.1080/ 17565529.2014 .886992

Saito N (2013) Mainstreaming climate change adaptation in least developed countries in South and Southeast Asia. Mitig Adapt Strateg Glob Chang 18(6):825-849. https://doi.org/10.1007/s11027-0129392-4

Scanlon J, Nobbe C (2010) Creating the Capacity for Decentralized, SelfGoverning Adaptations to Climate Change, In: Climate Governance and Development, Berlin Workshop Series. The World Bank, Washington, DC pp 133-148

Schäfer L, Kaloga A, Kreft S, Jennings M, Schalatek L, Munyaradzi F (2014) Learning from Direct Access Modalities in Africa. Germanwatch e.V., Bonn. http://www.germanwatch.org/en/9475. Accessed 23 Oct 2017

Schipper ELF, Ayers J, Reid H, Huq S, Rahman A (2014) Communitybased adaptation to climate change: scaling it up. Routledge

Schneider A (2003) Decentralization: conceptualization and measurement. Stud Comp Int Dev 38(3):32-56. https://doi.org/10.1007/ BF02686198

Sherman MH, Ford JD (2014) Stakeholder engagement in adaptation interventions: an evaluation of projects in developing nations. Clim Pol 14(3):417-441. https://doi.org/10.1080/14693062.2014. 859501

Soanes M, Rai N, Steele P, Shakya C, Macgregor J (2017) Delivering real change: getting international climate finance to the local level [IIED Working Paper]. International Institute for Environment and Development. https://pubs.iied.org/10178IIED/. Accessed 18 Jan 2019

Sovacool BK, Baker L, Martiskainen M, Hook A (2019) Processes of elite power and low-carbon pathways: experimentation, financialisation, and dispossession. Glob Environ Chang 59: 101985. https://doi.org/10.1016/j.gloenvcha.2019.101985

Sprain L (2017) Paradoxes of public participation in climate change governance. Good Soc 25(1):62-80. https://doi.org/10.5325/ goodsociety.25.1.0062

Tacconi L (2007) Decentralization, forests and livelihoods: theory and narrative. Glob Environ Chang 17(3):338-348. https://doi.org/10. 1016/j.gloenvcha.2007.01.002

TANGO International and ODI (2015) First phase independent evaluation of the Adaptation Fund. World Bank. https://www.adaptationfund.org/document/evaluation-of-the-fund-stage-1/. Accessed 25 Oct 2017
Titz A, Cannon T, Krüger F (2018). Uncovering ‘community’: challenging an elusive concept in development and disaster related work. Societies, 8(3), 71. https://doi.org/10.3390/soc8030071

Uittenbroek CJ, Janssen-Jansen LB, Runhaar HAC (2013) Mainstreaming climate adaptation into urban planning: overcoming barriers, seizing opportunities and evaluating the results in two Dutch case studies. Reg Environ Chang 13(2):399-411. https:// doi.org/10.1007/s10113-012-0348-8

UNDP (2012) Readiness for climate finance. A framework for understanding what it means to be ready to use climate finance. United Nations Development Programme. http://www.tr.undp.org/content/ dam/turkey/docs/Publications/EnvSust/UNDP-Readiness_for Climate Finance.pdf. Accessed 4 Aug 2017

UNDP (2014) Guidance note on how to plan and mainstream community-based adaptation at the local, sub-national and national levels. United Nations Development Programme. https://sgp.undp. org/index.php?option=com_docman\&view=document $\&$ layout $=$ default\&alias=499-guidance-note-on-how-to-plan-and-mainstreamcommunity-based-adaptation-at-the-local-sub-national-andnational-levels\&category slug=global-publications \&Itemid=289\#. WH4iofl95m8. Accessed 17 Jan 2017

UNFCCC (2010) G-77 and China proposal financial mechanism for meeting financial commitments under the convention. UNFCCC. http://unfccc.int/files/kyoto_protocol/application/pdf/g77_china financing_1.pdf. Accessed 24 Oct 2017

UNFCCC (2015) Synthesis report on the aggregate effect of the intended nationally determined contributions (FCCC/CP/2015/7). UNFCCC. http://unfccc.int/resource/docs/2015/cop21/eng/07.pdf. Accessed 19 Oct 2017

United Nations (2008) Participatory governance and the millennium development goals (MDGs) (ST/ESA/PAD/SER.E/119. Publication based on the Expert Group Meeting on Engaged Governance: citizen participation in the implementation of the developmental goals including the millennium development goals (MDGs) 1-2 November 2006 New York). United Nations. https:// publicadministration.un.org/publications/content/PDFs/E-Library\% 20Archives $/ 2008 \% 20$ Participatory $\% 20$ Governance $\% 20$ and $\%$ 20MDGs.pdf. Accessed 22 July 2017

van Aalst MK, Cannon T, Burton I (2008) Community level adaptation to climate change: the potential role of participatory community risk assessment. Glob Environ Chang 18(1):165-179. https://doi.org/10. 1016/j.gloenvcha.2007.06.002

Publisher's note Springer Nature remains neutral with regard to jurisdictional claims in published maps and institutional affiliations. 